\title{
Variability of black carbon deposition to the East Antarctic Plateau, 1800-2000 AD
}

\author{
M. M. Bisiaux ${ }^{1}$, R. Edwards ${ }^{1,2}$, J. R. McConnell ${ }^{1}$, M. R. Albert ${ }^{3}$, H. Anschütz ${ }^{4}{ }^{*}$, T. A. Neumann ${ }^{5}$, E. Isaksson ${ }^{4}$, and \\ J. E. Penner ${ }^{6}$ \\ ${ }^{1}$ Desert Research Institute, Division of Hydrologic Sciences, Reno, NV, USA \\ ${ }^{2}$ Curtin University, Imaging and Applied Physics, Perth, WA, Australia \\ ${ }^{3}$ Thayer School of Engineering, Dartmouth College, Hanover, NH 03755-8000, USA \\ ${ }^{4}$ Norwegian Polar Institute, Troms $\varnothing$, Norway \\ ${ }^{5}$ NASA Goddard Space Flight Center, Greenbelt, MD, USA \\ ${ }^{6}$ University Michigan, Ann Arbor, MI, USA \\ *now at: Norwegian Geotechnical Institute, Oslo, Norway
}

Correspondence to: M. M. Bisiaux (marion.ma.bisiaux@gmail.com)

Received: 14 November 2011 - Published in Atmos. Chem. Phys. Discuss.: 22 November 2011

Revised: 15 March 2012 - Accepted: 21 March 2012 - Published: 26 April 2012

\begin{abstract}
Refractory black carbon aerosols (rBC) from biomass burning and fossil fuel combustion are deposited to the Antarctic ice sheet and preserve a history of emissions and long-range transport from low- and mid-latitudes. Antarctic ice core $\mathrm{rBC}$ records may thus provide information with respect to past combustion aerosol emissions and atmospheric circulation. Here, we present six East Antarctic ice core records of $\mathrm{rBC}$ concentrations and fluxes covering the last two centuries with approximately annual resolution (cal. yr. 1800 to 2000). The ice cores were drilled in disparate regions of the high East Antarctic ice sheet, at different elevations and net snow accumulation rates. Annual $\mathrm{rBC}$ concentrations were log-normally distributed and geometric means of annual concentrations ranged from 0.10 to $0.18 \mu \mathrm{g} \mathrm{kg}^{-1}$. Average $\mathrm{rBC}$ fluxes were determined over the time periods 1800 to 2000 and 1963 to 2000 and ranged from 3.4 to $15.5 \mu \mathrm{g} \mathrm{m}^{-2} \mathrm{a}^{-1}$ and 3.6 to $21.8 \mu \mathrm{g} \mathrm{m}^{-2} \mathrm{a}^{-1}$, respectively. Geometric mean concentrations spanning 1800 to 2000 increased linearly with elevation at a rate of $0.025 \mu \mathrm{g} \mathrm{kg}^{-1} / 500 \mathrm{~m}$. Spectral analysis of the records revealed significant decadal-scale variability, which at several sites was comparable to decadal ENSO variability.
\end{abstract}

\section{Introduction}

Nanoparticles of refractory black carbon (rBC, soot) aerosols are emitted to the atmosphere during fires and fossil fuel combustion and transported over long distances at the hemisphere-scale (Seiler and Crutzen, 1980; Andreae et al., 2005; Crutzen and Andreae, 1990). Because of their strong light absorption properties, rBC nanoparticles alter air temperature, snow albedo and impact climate (Moosmüller et al., 2009; Ramanathan and Carmichael, 2008; Ramanathan et al., 2001; Jacobson, 2001; Flanner et al., 2007; Penner et al., 2002). The incorporation of future emissions scenarios is therefore a key parameter for global climate modellers (Ramanathan and Carmichael, 2008).

However, even if surveys of $\mathrm{rBC}$ atmospheric concentrations and fire occurrence are being constructed for the last few decades thanks to the development of new satellite tools (Ito and Penner, 2004; Chung et al., 2005), the history of rBC fire emissions over last two centuries is incomplete (Mouillot and Field, 2005). Indeed, a detailed fire history over periods covering the pre-industrial time to the modern era is lacking, notably because common fire proxies such as charcoal deposits or gas emissions reconstructions from ice cores cannot reconstruct large spatial variability at inter-annual time scales (Marlon et al., 2008; Wang et al., 2010). Nonetheless, fire regimes are likely to have been modified by anthropogenic 
activities such as tropical deforestation, land-clearing practices or through natural changes in precipitation and temperature patterns with the changing climate (Dube, 2009; Nitschke and Innes, 2008; Bowman et al., 2009).

Recently, several studies have directly used $\mathrm{rBC}$ from ice cores to estimate emissions from past combustion, spanning the transition from the pre-industrial to the modern era. In the Northern Hemisphere, ice cores from Greenland and the Himalayas have shown the impact of coal combustion on $\mathrm{rBC}$ snow concentrations (McConnell et al., 2007; McConnell, 2010; Kaspari et al., 2011). In the Southern Hemisphere (SH), two high resolution $\mathrm{rBC}$ records from Antarctica have recently been used to investigate the evolution of forest and grass fires (Bisiaux et al., 2012). The records, from the West Antarctic Ice Sheet (WAIS) and Law Dome, spanned the time period 1850-2001 and showed large-scale changes in $\mathrm{rBC}$ deposition linked to climatic oscillations such as El Niño Southern Oscillation (ENSO) and the anthropogenic modification of fire regimes.

However, the contribution of each continent to Antarctic $\mathrm{rBC}$ deposition remains unknown, as well as the influence of atmospheric transport to sites located in the Atlantic sector of Antarctica. Ice core sites located at high elevation on the East Antarctic Plateau in East Antarctica may record different variability than the sites previously studied on coastal East Antarctica and the West Antarctic Ice Sheet (Bisiaux et al., 2012). The present study uses rBC paleorecords from the Atlantic sector to investigate spatial and temporal variability of $\mathrm{rBC}$ deposition and the link with emissions sources. We use six ice core records from Dronning Maud Land (Fig. 1) and focus on the cal. yr. period 1800-2000, covering preindustrial and modern eras. These sites have much lower annual snow accumulation rates $\left(20-60 \mathrm{~kg} \mathrm{~m}^{-2} \mathrm{a}^{-1}\right)$ compared to the sites investigated by Bisiaux et al. (2012) (150$200 \mathrm{~kg} \mathrm{~m}^{-2} \mathrm{a}^{-1}$ ) and have a lower temporal resolution (annual to multi-annual). We use accumulation calculations from Anschütz et al. (2011) to estimate rBC fluxes at these sites and the importance of precipitation on $\mathrm{rBC}$ concentrations. Periodic oscillations in the $\mathrm{rBC}$ records are investigated through spectral and multiple regression analysis and compared to sodium (Na) records (measured simultaneously) to evaluate the influence of transport in the observed $\mathrm{rBC}$ variability.

\section{Drilling sites and methods}

\subsection{Drilling site locations and characteristics}

The sites are all located on the East Antarctic Plateau (elevation $>2500 \mathrm{~m}$ ), in Dronning Maud Land (Fig. 1). The cores were drilled during two exploratory traverses by a Norwegian-American team (NUS) in the summer of 2007 (cores "07-X") and in the summer of 2008 (cores "08-X'). Latitudes, longitudes and elevations are compiled in Table 1.



Fig. 1. Map of the traverse route 2007/2008 (black line) and 2008/2009 (blue line) with drill described in this study sites from both legs indicated (NUS07-X and NUS08-X). Relevant stations in the area of investigation are shown as well. Elevation contour lines are in $100 \mathrm{~m}$ intervals. The map was compiled by K. Langley and S. Tronstad (Norwegian Polar Institute) and adapted by Anschütz et al. (2011) for this study. The locations of the WAIS and Law Dome drilling sites are shown on the inset as red dots.

Cores NUS08-4 and NUS08-5 were drilled in adjacent locations and only $\sim 17 \mathrm{~km}$ apart. All cores are firn cores of total length under $90 \mathrm{~m}$, of which we present the top part, down to a depth corresponding to cal. yr. 1800 (Table 1). However, the top dates are not common to all cores (due largely to fragile near-surface firn sections) and range from cal. yr. 1989 for NUS 07-5 to cal. yr. 2008 for NUS 07-7(Table 1).

\subsection{Ice core analysis}

Longitudinal sections of the NUS ice cores were analysed from 2008 to 2010 at the Desert Research Institute on an icecore melter continuous flow analysis system with in-line rBC measurements. The inner $1 \mathrm{~cm}^{2}$ of the sections were used for 
Table 1. Sites coordinates, rBC concentrations and fluxes, annual accumulation for this study and previous study by Bisiaux et al. (2012), for two periods of time (since 1800 and since 1963).

\begin{tabular}{|c|c|c|c|c|c|c|c|c|c|}
\hline & & \multicolumn{6}{|c|}{ This study } & \multicolumn{2}{|c|}{ Bisiaux et al. (2012) } \\
\hline & & NUS07-1 & NUS07-2 & NUS07-5 & NUS07-7 & NUS08-4 & NUS08-5 & WAIS (WDC06A) & Law Dome (DSSW19K) \\
\hline Lat - long & & $\begin{array}{l}73^{\circ} 43^{\prime} \mathrm{S}- \\
07^{\circ} 59^{\prime} \mathrm{E}\end{array}$ & $\begin{array}{l}76^{\circ} 04^{\prime} \mathrm{S}- \\
22^{\circ} 28^{\prime} \mathrm{E}\end{array}$ & $\begin{array}{l}78^{\circ} 39^{\prime} \mathrm{S}- \\
35^{\circ} 38^{\prime} \mathrm{E}\end{array}$ & $\begin{array}{l}82^{\circ} 04^{\prime} \mathrm{S}- \\
54^{\circ} 53^{\prime} \mathrm{E}\end{array}$ & $\begin{array}{l}82^{\circ} 49^{\prime} \mathrm{S}_{-} \\
18^{\circ} 54^{\prime} \mathrm{E}\end{array}$ & $\begin{array}{l}82^{\circ} 38^{\prime} \mathrm{S}- \\
17^{\circ} 52^{\prime} \mathrm{E}\end{array}$ & $\begin{array}{l}79^{\circ} 46^{\prime} \mathrm{S}- \\
112^{\circ} 08^{\prime} \mathrm{W}\end{array}$ & $\begin{array}{l}66^{\circ} 73^{\prime} \mathrm{S}- \\
112^{\circ} 83^{\prime} \mathrm{E}\end{array}$ \\
\hline Elevation (in m a.s.l.) & & 3174 & 3582 & 3619 & 3725 & 2552 & 2544 & 1766 & 1390 \\
\hline $\begin{array}{l}\text { Depth of yr } 1800 \text { for this } \\
\text { Study/total core depth (in m) }\end{array}$ & & $22.2 / 30.5$ & $16.4 / 90.4$ & $12.6 / 89.5$ & $14.6 / 90.6$ & $18.05 / 30$ & $17.5 / 92$ & - & - \\
\hline Period covered & & $1800-2006$ & $1800-1993$ & $1800-1989$ & $1800-2008$ & $1800-2004$ & $1800-1993$ & $1850-2001$ & $1850-2001$ \\
\hline Number of data points & & 2154 & 1501 & 1111 & 1308 & 1672 & 1616 & 4860 & 2883 \\
\hline $\begin{array}{l}\text { Annual } \mathrm{rBC} \text { conc. (geometric } \\
\text { mean) in } \mu \mathrm{gg}^{-1} \ldots\end{array}$ & $\begin{array}{r}\ldots \text { since } 1800 \\
\ldots \text { range }(2 \sigma)^{\mathrm{a}} \\
\ldots \text { since } 1963 \\
\ldots \text { range }(2 \sigma)^{\mathrm{a}}\end{array}$ & $\begin{array}{l}0.16 \\
0.09 \text { to } 0.26 \\
0.14 \\
0.08 \text { to } 0.27\end{array}$ & $\begin{array}{l}0.12 \\
0.07 \text { to } 0.19 \\
0.14 \\
0.08 \text { to } 0.24\end{array}$ & $\begin{array}{l}0.14 \\
0.08 \text { to } 0.26 \\
0.18 \\
0.14 \text { to } 0.24\end{array}$ & $\begin{array}{l}0.18 \\
0.12 \text { to } 0.27 \\
0.19 \\
0.13 \text { to } 0.29\end{array}$ & $\begin{array}{l}0.10 \\
0.06 \text { to } 0.18 \\
0.15 \\
0.08 \text { to } 0.26\end{array}$ & $\begin{array}{l}0.11 \\
0.07 \text { to } 0.18 \\
0.12 \\
0.08 \text { to } 0.20\end{array}$ & $\begin{array}{l}0.08 \\
0.05 \text { to } 0.12 \\
0.08 \\
0.05 \text { to } 0.12\end{array}$ & $\begin{array}{l}0.09 \\
0.05 \text { to } 0.2 \\
0.07 \\
0.04 \text { to } 0.15\end{array}$ \\
\hline $\begin{array}{l}\text { Annual accumulation } \\
\text { in } \\
\text { in } \mathrm{kg} \mathrm{m}^{-2} \mathrm{a}^{-1} \ldots\end{array}$ & $\begin{array}{r}\text {...since } 1815 \\
\ldots \text { since } 1963\end{array}$ & $\begin{array}{l}52.0 \pm 2.0 \\
55.9 \pm 3.9\end{array}$ & $\begin{array}{l}33.0 \pm 0.7 \\
28.0 \pm 2.0\end{array}$ & $\begin{array}{l}24.0 \pm 0.5 \\
20.1 \pm 1.4\end{array}$ & $\begin{array}{l}29.4 \pm 0.6 \\
26.1 \pm 1.9\end{array}$ & $\begin{array}{l}36.7 \pm 0.9 \\
36.1 \pm 2.1\end{array}$ & $\begin{array}{l}35.0 \pm 0.8 \\
37.6 \pm 2.3\end{array}$ & $\begin{array}{l}200 \pm 3.4 \\
-\end{array}$ & $\begin{array}{l}150 \pm 3.1 \\
-\end{array}$ \\
\hline $\begin{array}{l}\text { Annual } \mathrm{rBC} \text { fluxes (geometric } \\
\text { mean) in } \mu \mathrm{g} \mathrm{m}^{-2} \mathrm{a}^{-1} \ldots\end{array}$ & $\begin{array}{c}\ldots \text { since } 1800 \mathrm{c} \\
\ldots \text { range }(2 \sigma) \\
\ldots \text { since } 1963 \\
\ldots \text { range }(2 \sigma)\end{array}$ & $\begin{array}{l}8.3 \\
4.6 \text { to } 14.2 \\
7.8 \\
4.0 \text { to } 15.8\end{array}$ & $\begin{array}{l}3.9 \\
2.5 \text { to } 6.2 \\
3.9 \\
2.4 \text { to } 7.3\end{array}$ & $\begin{array}{l}3.4 \\
1.8 \text { to } 6.3 \\
3.62 \\
2.6 \text { to } 5.2\end{array}$ & $\begin{array}{l}5.3 \\
3.5 \text { to } 8.0 \\
5 \\
3.1 \text { to } 8.0\end{array}$ & $\begin{array}{l}3.7 \\
2.1 \text { to } 6.9 \\
5.4 \\
2.7 \text { to } 10.0\end{array}$ & $\begin{array}{l}3.9 \\
2.2 \text { to } 6.5 \\
4.5 \\
2.7 \text { to } 8.0\end{array}$ & $\begin{array}{l}16 \\
9.8 \text { to } 24.4 \\
- \\
-\end{array}$ & $\begin{array}{l}13.5 \\
7.3 \text { to } 30.6 \\
- \\
-\end{array}$ \\
\hline
\end{tabular}

a Multiplicative standard deviation.

${ }^{\mathrm{b}}$ From Anschütz et al. 2011.

c We assume same accumulation rate for the $1800-1815$ periods.

the $\mathrm{rBC}$ analysis according to the method previously used in McConnell et al. (2007) and McConnell (2010), and described in detail by Bisiaux et al. (2012). The rBC analysis consisted of an ultrasonic nebulizer/desolvation system (CETAC UT5000) coupled to a Single Particle Soot Photometer (SP2, Droplet Measurement Technologies, Boulder, Colorado). In this system, ice core meltwater was nebulized and desolvated to form a dry aerosol. The aerosol then passed into the SP2, where individual particles in the diameter range $\sim 70-400 \mathrm{~nm}$ were heated up to incandescence by an $\mathrm{Nd}$ YAG laser $(1064 \mathrm{~nm})$, and the emitted radiation was measured by optical detectors (photomultiplier tubes). Individual particle masses were determined using calibration data generated from the introduction of $\mathrm{rBC}$ particles of known mass directly into the SP2. Additional calibrations of the SP2 coupled to the ultrasonic nebulizer (USN) were performed daily using rBC colloids. These calibrations were used to account for $\mathrm{rBC}$ losses in the USN. Depth resolution of the analytical system was estimated at $1 \mathrm{~cm}$.

\subsection{Ice core dating}

Annual layer counting was not possible for these NUS cores and dating was based on the identification and mapping between ice cores of a number of chemical markers corresponding to explosive volcanic eruptions. Specifically, we used continuous, high-depth-resolution measurements of non-seasalt sulphur (nssS) in the WAIS Divide (WDC06A) and NUS ice cores to identify layers with significant volcanic sulphur concentrations. Dating of the volcanic horizons was performed using annual layer counting in the WAIS Divide ice core (Bisiaux et al., 2012). The WAIS core volcanic chronology was then applied to the NUS cores' volcanic horizons
(Table 1). Although well-known large volcanic events (e.g. Tambora, Krakatoa, Agung) were included in the chronology, smaller, less-known volcanic events were used to fill in the depth-age relationships where possible (a total of seven tie points: cal. years 1810, 1816, 1837, 1863/4, 1884, 1965, 1991/2). Dating between the volcanic horizons assumed uniform accumulation between horizons. Snow accumulation rates (net) at each site (Table 1) were based on these depthage relationships and ice-core depth/density profiles (Anschütz et al., 2009, 2011) and restricted to average rates between the dating horizons (which included the ice cap surface).

The number of $\mathrm{rBC}$ data points varied from 6 to 10 per year. However, the dating uncertainty is likely on the order of several years due to the low annual snow accumulation rates and physical processes, such as the redistribution of snow by wind. Overall, the dating uncertainty may be as large as $\pm 5 \mathrm{yr}$ between the dating horizons. The depth-age relationship of the NUS 07-1 core benefited from previously published accumulation rate data (Isaksson et al., 1999) and was used as the basis of further refinement of the 08-5 and 08-4 depth-age relationship using decadal trends in the rBC records. The refinement process consisted of warping the 08-4 and 08-5 rBC non-linear trend (described in Sect. 2.4) peaks and troughs to the 07-1 non-linear $\mathrm{rBC}$ trend (within the constraints of the volcanic chronology) using the Analyseries software (Paillard et al., 1996) lineage tool. The refined depth-age relationships resulted in coherent non-linear trends between the 08-4 and 08-5 records, which were drilled in the same region (separated by $17 \mathrm{~km}$ ). 


\subsection{Data analysis}

\subsubsection{Period studied}

The study focused on two time periods, including 1800 to 1990-2003 (time period depending on the ice core considered) and 1963 to $1990-2003$. These time periods were selected to coincide with the snow accumulation calculations by Anschütz et al. (2011). For the purpose of this study, the snow accumulation rate from the time period 1809 to 1815 was assumed to extend to 1800 .

\subsubsection{Concentrations}

The frequency distributions of the ice core $\mathrm{rBC}$ concentrations were determined to be lognormal. Statistics, such as the average and standard deviation, and mathematical operations such as re-sampling, smoothing, trend and spectral analysis, etc. were therefore performed in log-space (Limpert et al., 2001) to give "robust" geometric rather than arithmetic statistics. Note that here the geometric standard deviation is the multiplicative standard deviation (Limpert et al., 2001), which covers $68.3 \%$ of the variability, corresponding to $\sigma \min _{\text {conc }}=$ geometric mean . geometric standard deviation, and $\sigma \max _{\text {conc }}=$ geometric mean/geometric standard deviation. Prior to spectral analysis the concentration data were re-sampled to an annual time scale using the "robust" piecewise linear interpolation method described by Paillard et al. (1996). A 21-yr smoothing window was used to capture decadal-scale variability and was performed using the non-parametric Nadaraya-Watson kernel density regression method (Watson, 1964; Nadaraya, 1965). The time window used for the smoothing represents a trade-off between the temporal resolution of the different records and the time span of the records, and variability in the later half of the 20th century. Monotonic trends were estimated using the nonparametric Thiel-Sen approach (Gilbert, 1987; Önöz and Bayazit, 2003), while non-linear trends were calculated with singular spectrum analysis (SSA) using Kspectra software (Ghil et al., 2002) at a $95 \%$ Kendall level of confidence. Significant non-linear trends were reconstructed using the Kspectra SSA tool, which partially reconstructs the time series based on a linear combination of trend principal components (Ghil et al., 2002). The non-linear trend data were then back-transformed from log-space and normalized (Z-scores calculated using the arithmetic mean and standard deviation of the complete trend reconstruction) for easier comparison of variability between records.

\subsubsection{Deposition fluxes}

Flux calculations were based on longer-term average snow accumulation estimates obtained by Anschütz et al. (2011) from the volcanic chronology. Atmospheric fluxes of $\mathrm{rBC}$ were estimated by multiplying annual $\mathrm{rBC}$ concentrations and accumulation rates corresponding to the two time periods chosen. Fluxes uncertainties were estimated as $\sigma \min _{\text {flux }}=\sigma \min _{\text {conc }} \cdot\left\{\right.$ accumulation $-\sigma \min _{\text {accu }}$ ) and $\sigma \max _{\mathrm{flux}}=\sigma \max _{\mathrm{conc}} \cdot\left(\right.$ accumulation $\left.+\sigma \max _{\mathrm{accu}}\right)$.

\subsubsection{Spectral analysis}

Spectral analysis was conducted using Analyseries software (Paillard et al., 1996). Significant periodic oscillations in the $\mathrm{rBC}$ and $\mathrm{Na}$ ice core records and their spectral coherence were investigated using the Blackman-Tukey method with a Bartlett window. In this study we define coherence as the fraction of common variance between two time series $x$ and $y$ through a linear relation, considering non-zero when coefficients reach values $>0.38$ (Paillard et al., 1996). Here, we use raw data re-sampled to a $0.4 \mathrm{yr}$ step with piecewise linear interpolation to perform the calculations in order to remove lower frequencies, but to keep the eventual annual cycles. Coherence coefficients are given with 3 levels of confidence (low, medium and high), of which we only present the medium level, and only for coefficients $>0.38$ in Fig. 6 . Principal components \#1 extracted from records are calculated with an embedding dimension of 20 and theory from Vautard and Ghil (1989).

\section{Results and discussion}

\subsection{Concentrations and fluxes}

Concentrations of rBC were found to be log-normally distributed with geometric means of annual concentrations ranging from 0.10 to $0.18 \mu \mathrm{g} \mathrm{kg}^{-1}$ since 1800 and from 0.12 to $0.19 \mu \mathrm{g} \mathrm{kg}^{-1}$ since 1963 (Table 1). Overall, the NUS ice core geometric mean $\mathrm{rBC}$ concentrations were higher than the concentrations previously determined at lower elevation sites for the same time periods at WAIS (WDC06A) and Law Dome (DSSW19K) (Bisiaux et al., 2012). We attribute this difference to the very low annual snow accumulation rates on the plateau (Table 1) and thus to a low rBC dilution by snow, suggesting a significant fraction of dry versus wet deposited rBC. However, annual rBC fluxes estimates since 1800 are still lower $\left(3.4\right.$ to $8.3 \mu \mathrm{g} \mathrm{m}^{-2} \mathrm{a}^{-1}$ ) than those determined for the WDC06A and DSSW19K (Table 1).

The time series of annual and 21-yr smoothed rBC concentrations at all NUS sites are shown in Fig. 2. Significant monotonic trends, with superimposed decadal variability (for the whole period 1800 - onwards, MannKendall test double-sided p-values $<0.0001$ ), were found in annual $\mathrm{rBC}$ concentrations at sites $07-5,08-4$ and 08-5 (Fig. 3a). The trends at these sites represented an increase of $\sim 0.03 \pm 0.01 \mu \mathrm{g} \mathrm{kg}^{-1} / 100 \mathrm{yr}$. Comparison of the records at annual resolution revealed no significant cross-correlations, including for sites 08-4 and 08-5, which were within $17 \mathrm{~km}$ of each other. We conclude that surface processes (accumulation rate variability, sastrugi, blowing snow, and snow sublimation) prevent the analysis of $\mathrm{rBC}$ signal at annual 


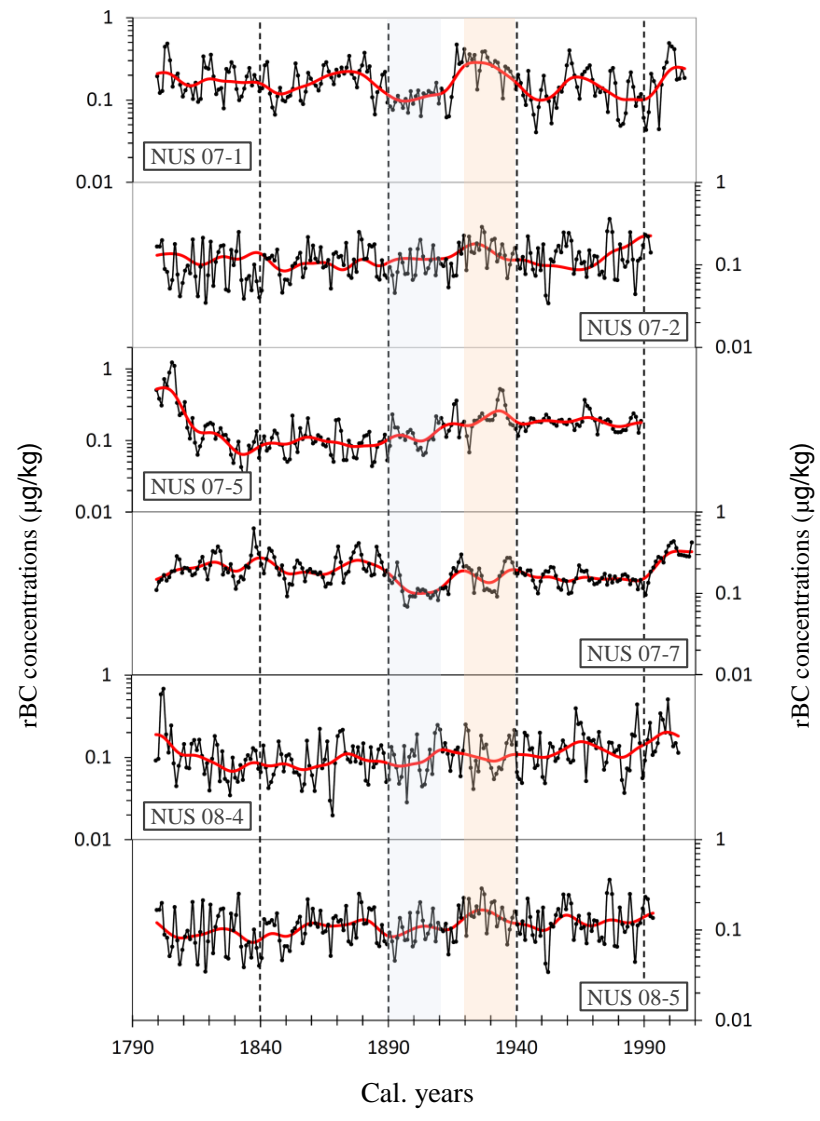

Fig. 2. Time series of $\mathrm{rBC}$ concentrations. Black line is annual (piece-wise linear integration interpolation of log raw data) and red line is $21 \mathrm{yr} \mathrm{k}$-smooth on annual (calculated in log space). The periods of relatively low values (1890-1910) and high values (19201940), as described in Fig. 3, are indicated as shaded areas.

time scales and restrain the resolution to interannual/decadalscales (Pomeroy et al., 1999).

Decadal-scale variability was investigated using singular spectrum analysis non-linear trend reconstruction (Ghil et al., 2002). Significant non-linear trends over the entire period (1800 - onwards, $p<0.05$, Mann-Kendall trend test) are shown in Fig. $3 \mathrm{~b}-\mathrm{c}$ (normalized as Z-scores). Nonlinear trends from sites 08-4 and 08-5 (which were independently mapped to the 07-1 time scale) were highly correlated $\left(r=0.64, r^{2}=0.41, n=195, p<0.01\right)$. Correlation coefficients for the other records were insignificant, but with some common features. Comparison of these non-linear trends, cf. Fig. 3b-c, revealed a period of low concentrations from cal. yr. 1890 to $\sim 1915$, common to observations made at WAIS and Law Dome (Bisiaux et al., 2012). Here, however, this drop is followed by a period of relatively high concentrations until $\sim 1940$ and peaking locally in the 1930s. While this peak was detected in the high resolution record from Law Dome (Bisiaux et al., 2012), it was absent from the WAIS record. With the exception of site 07-2 (Fig. 3b-c),

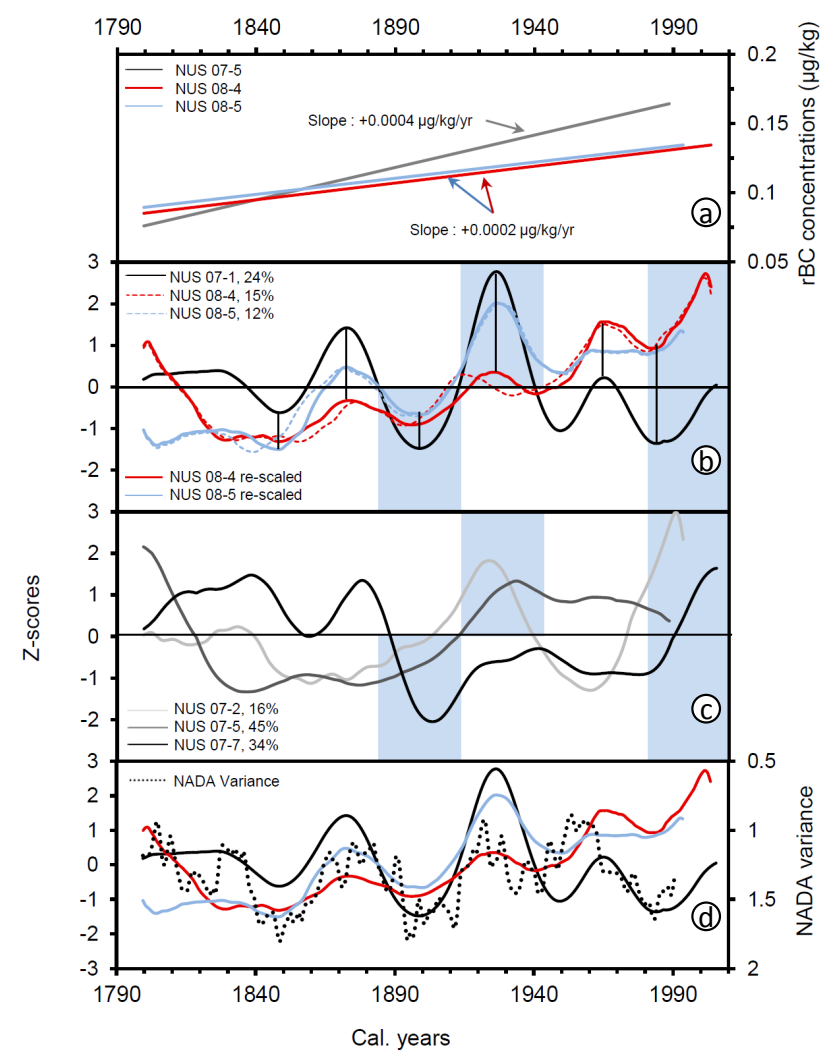

Fig. 3. (a) Monotonic trends for sites 07-5, 08-4 and 08-5 (Kendall significance $=99 \%)$. (b, c, d) Non-linear trends normalized as Z-scores (Kspectra software, Kendall significance $=95 \%$ ) for the six NUS rBC records, as a function of time. Corresponding fraction of record variability is indicated next to record name (\%). (b) Comparison of twin sites 08-4 and 08-5, re-scaled from 07-1 dating (plain curve). Original dating is shown as dotted line. (c) Other three records 07-2, 07-5 and 07-7. Shaded areas highlight specifically common features and/or trends. (d) Comparison of trends (Z-scores) from sites 07-1, 08-4, 08-5 with NADA variance (ENSO long term variability) in dotted line, scale inverted.

the NUS $\mathrm{rBC}$ records also lacked the period of low variance, from $\sim 1940$ to $\sim 1980$, found in the WAIS and Law Dome records. Finally, the last 20 yr (1980-2000) show an increasing trend for the cores' recording this period, which was also noted by Bisiaux et al. (2012) for WAIS and Law Dome.

\subsection{Effect of elevation}

The geometric average of the annual $\mathrm{rBC}$ concentrations at each site was found to increase linearly with elevation, cf. Table 1 for site elevation. Linear correlation coefficient $(r)$ was 0.81 when concentrations were averaged since $1800\left(r^{2}=\right.$ $0.67, n=8, p=0.01$ ), and 0.92 when concentrations were averaged since $1963\left(r^{2}=0.86, n=8, p<0.01\right)$ (Fig. 4a). The slope of this linear regression corresponds to an increase of 0.015 and $0.025 \mu \mathrm{g}$ for an elevation gain of $500 \mathrm{~m}$, respectively. 

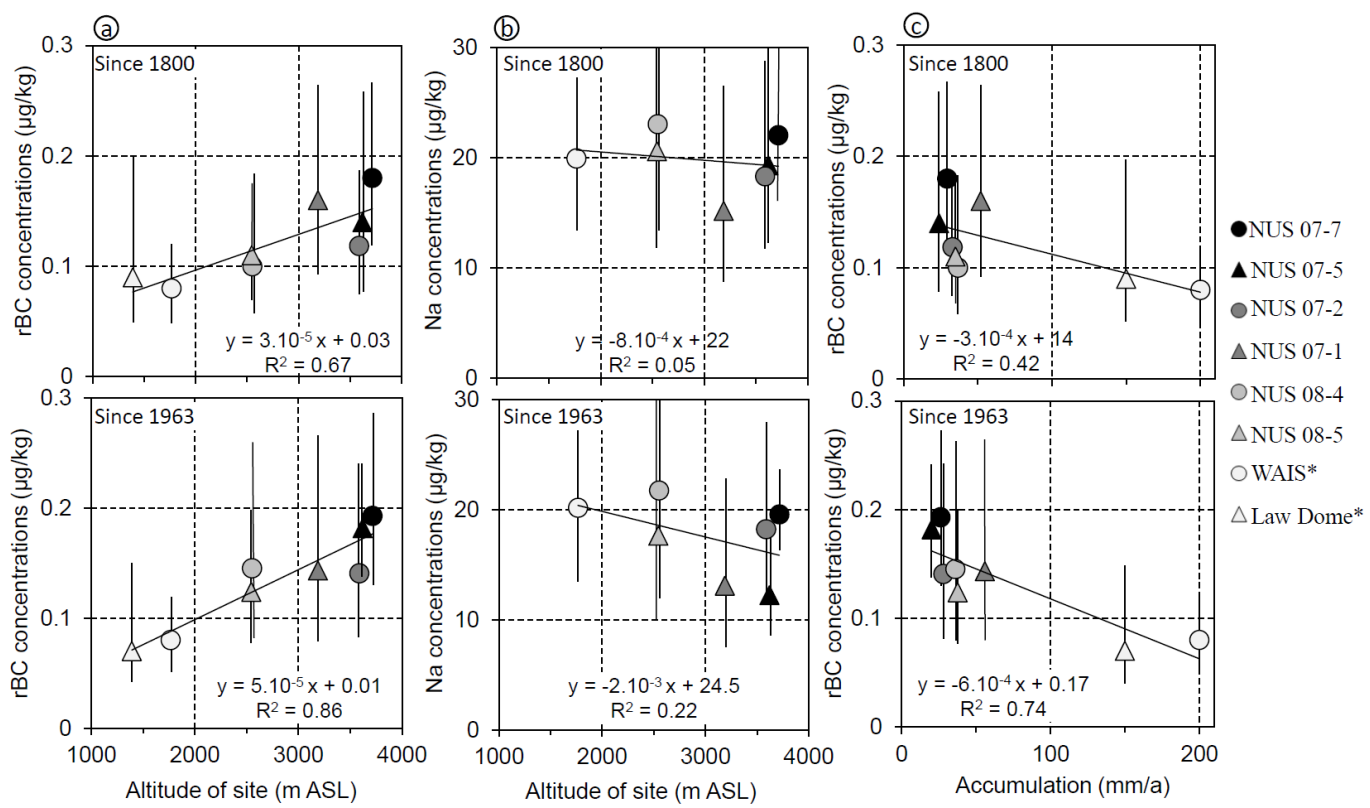

Fig. 4. Geometric mean $\mathrm{rBC}$ (a) and $\mathrm{Na}$ (b) concentrations $\sim$ since cal. yr. 1800 (top) and 1963 (bottom) as a function of site altitude. For Na, regression line was calculated without the maritime site "Law Dome". (c) Geometric mean rBC concentrations as a function of accumulation after cal. yr. 1800 (top) and 1963 (bottom) (Anschütz et al., 2011). Uncertainty bars refer to Table 1. Regression lines and coefficients are based on geometric mean values. $r^{2}$ indicates the coefficient of determination. ${ }^{*}$ Values for Law Dome and WAIS from Bisiaux et al. (2012).

The increase of $\mathrm{rBC}$ with elevation was previously observed in the southern latitude atmospheres by Schwarz et al. (2010) and modelled for Arctic snow by Skeie et al. (2011). Stohl (2006) also modelled increased atmospheric loading in the southern latitudes and attributed this increase to $\mathrm{rBC}$ transport from lower latitudes towards the ice cap, along isentropic trajectories that may not reach the surface of the region lower than the plateau and remain at higher elevations.

To investigate whether $\mathrm{rBC}$ transport to the plateau is modulated by the intrusion of marine air masses, the variability of Na concentrations (geometric means) with elevation was also investigated. In this case, no significant relationship was found $\left(r^{2}=0.05, n=7, p>0.05\right)$ (Fig. 4b). This confirms observations previously made by Bertler et al. (2005), showing no link between increased elevation and $\mathrm{Na}$ concentrations for altitudes above $2000 \mathrm{~m}$. We hypothesize that this absence of correlation with elevation for $\mathrm{Na}$ and presence of correlation for $\mathrm{rBC}$ are due to both a difference in the sources of $\mathrm{Na}$ and $\mathrm{rBC}$ aerosols and to a difference in atmospheric transport. Indeed, the main sources of $\mathrm{Na}$ are marine aerosols, which are transported to the East Antarctic Plateau by low pressure systems (Sneed et al., 2011) and dry deposited (Fischer et al., 2007). Transport processes associated with $\mathrm{rBC}$, therefore, appear to be different from those associated with $\mathrm{Na}$. This suggests that $\mathrm{rBC}$ inputs to the atmosphere of the East Antarctic Plateau are not controlled by the intrusion of marine air masses and that transport in the upper troposphere may be important. Vertical profiles of
$\mathrm{rBC}$ in the near Antarctic atmosphere reported by Schwarz et al. (2010), who found that $\mathrm{rBC}$ increased with altitude. Here, wet removal processes limit the lifetime of $\mathrm{rBC}$ near the boundary layer, while dry air in the upper atmosphere increases the $\mathrm{rBC}$ residence time.

Snow water accumulation rates, on the contrary, do show a significant inverse trend with $\mathrm{rBC}$ concentrations, but only from 1963 onwards $\left(r^{2}=0.74, r=0.85, n=8, p<\right.$ $0.01)$ (Fig. 4c). However, this correlation is determined mainly by the WAIS and Law Dome data points, with NUS sites clustering around the same values (Fig. 4c). Uncertainties inherent in the net snow accumulation rate must also be considered. Acknowledging these caveats, the slope of the linear regression of $0.030 \mu \mathrm{g}$ in $\mathrm{rBC}$ for a $50 \mathrm{~mm}$ decrease in accumulation can be compared with the increase of $0.025 \mu \mathrm{g}$ $\mathrm{rBC}$ estimated for every $500 \mathrm{~m}$ in elevation, for the time period from 1800 to the present (Fig. 4a, top). Thus, for the two time periods shown in Fig. 4, the change in elevation may explain $\sim 80 \%$ of the difference in $\mathrm{rBC}$ geometric mean concentrations. Therefore, we suggest that the main process controlling the spatial differences in geometric rBC snow concentrations between the sites of the Antarctic Plateau is the decrease in accumulation and corresponding increase in rBC dry deposition, inducing less dilution of the particles. This relationship may explain the monotonic trend found for the record 07-5 (Sect. 3.1), which exhibits a decrease in accumulation rate from the period 1815 - onwards to the period 1963 - onwards (Anschütz et al., 2011; Isaksson et al., 1999), cf. Table 1. However, it is not as clear for the two other sites 


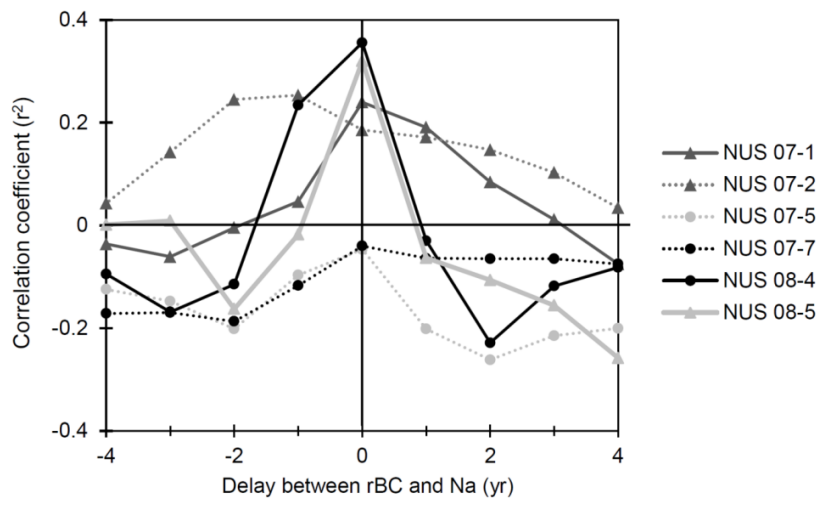

Fig. 5. Cross correlation coefficients between $\mathrm{Na}$ and $\mathrm{rBC}$ from the same record. Na leads $\mathrm{rBC}$ for delays $>0$ and $\mathrm{rBC}$ leads $\mathrm{Na}$ for delays $<0$.

displaying significant increasing monotonic trends, $08-4$ and 08-5, but no strong trend in accumulations(Table 1 ).

\subsection{Influence of transport}

For the sites $07-1,08-4$ and $08-5$, cross-correlations of the annual $\mathrm{rBC}$ and $\mathrm{Na}$ suggest common high frequency variability between the $\mathrm{rBC}$ and $\mathrm{Na}$ species at each site without leads or lags (Fig. 5). These data suggest a transport component linked to some of the high frequency variability. Nonlinear low frequency trends similar to those found in the $\mathrm{rBC}$ records (Fig. 3b-c) were not found in the Na records. According to Sodemann and Stohl (2009), precipitation in this high-altitude region of the Eastern Antarctic originates from sources located much further north than for the coastal regions. The lack of a correlation between the annual $\mathrm{rBC}$ data at the remaining sites and the non-linear trends at 08-4, 08-5 and $07-1$ suggests that the low frequency $\mathrm{rBC}$ variability may be linked to emission variability, or site specific atmospheric transport.

To test this hypothesis, the spectral coherence for $\mathrm{Na}$ and $\mathrm{rBC}$ was investigated (Fig. 6). This analysis determined the coherence between periodic signals in the $\mathrm{rBC}$ and $\mathrm{Na}$ time series. A high coefficient for a given frequency suggests that the two periodic signals have coherent variability. Sites 084 and 08-5 exhibit coherence coefficients higher than 0.38 (black line) for a large portion of the bandwidth. Notable exceptions are the ENSO band from $\sim 4$ to $7 \mathrm{yr}$ and at lower decadal frequencies. For sites 07-2 and 07-7, coherence is much lower and often $<0.38$, confirming observations made on cross-correlations between Na and rBC (Fig. 5). Coherences between $\mathrm{Na}$ and $\mathrm{rBC}$ for sites 07-1 and 07-5, were similar to 08-4 and 08-5 with less coherence at low frequencies $(<0.2$ cycles per year $)$.

The spectral power of $\mathrm{rBC}$ time series is shown as a red line in Fig. 6. Peaks of high power designate frequencies explaining some variability of the signal. If these power

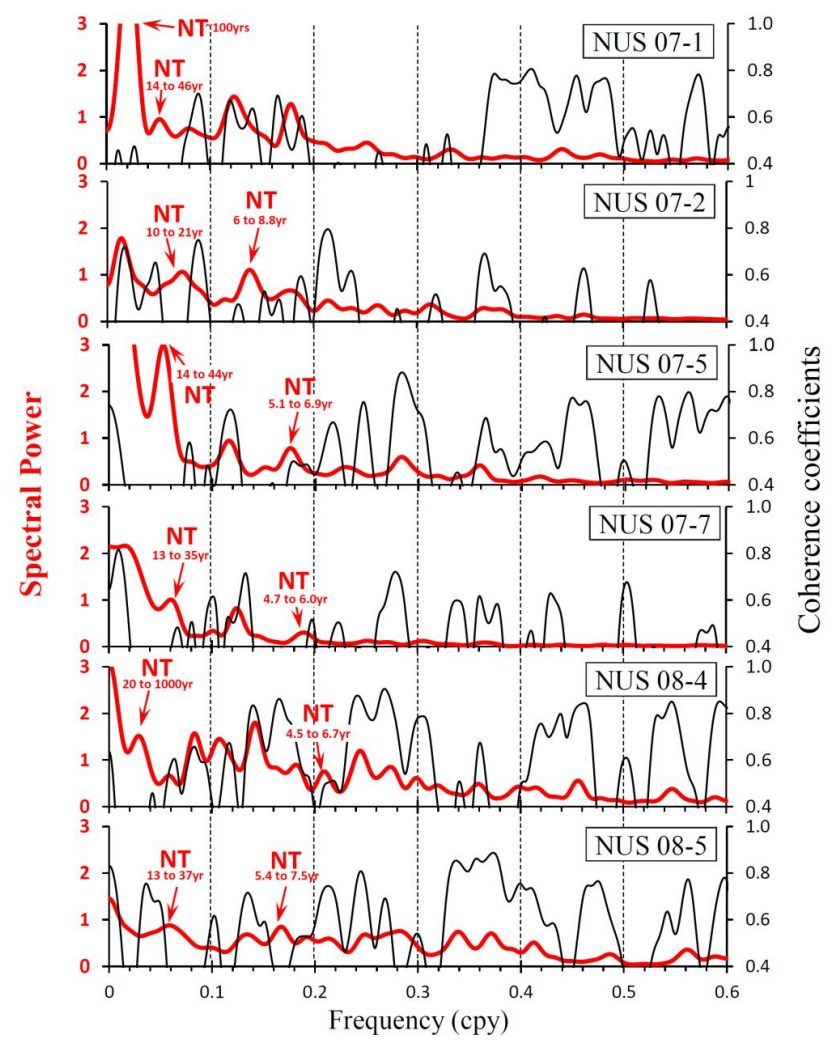

Fig. 6. Spectral power (red) of rBC NUS records and coherence coefficients (black) between $\mathrm{rBC}$ and $\mathrm{Na}$ investigated for the whole period (since 1800). Non-zero coherence is above 0.38 . Red letters "NT" stand for "Non Transport". They indicate periodic signals in the $\mathrm{rBC}$ records that are not coherent to $\mathrm{Na}$ (no black peak) and that are likely related to $\mathrm{rBC}$ emissions rather than regional to long range atmospheric transport. The red numbers below "NT" show the corresponding periodicity (in years).

peaks do not correspond to a peak in coherence between $\mathrm{Na}$ and $\mathrm{rBC}$ (black line), they indicate an oscillation that is not linked to common atmospheric transport (NT). A periodicity of $\sim 4.5$ to $7 \mathrm{yr}(\sim 0.17$ to 0.2$)$ is found common to sites $07-2$, $07-5,07-7,08-4$ and $08-5$. This period window suggests the influence of ENSO. However, even if an ENSO "signature" is present, none of the $\mathrm{rBC}$ records is statistically correlated to the ENSO index, which may be explained by two reasons. First, the records do not have the temporal resolution to adequately resolve the signal from noise. Second, ENSO has ,by nature, a dual effect on fire potential, by inducing drought on one side of the Pacific and floods on the other side, rendering a potential ENSO-fire signal very disparate (Krawchuk and Moritz, 2011).

However, a NT periodic oscillation of $\sim 15$ to $40 \mathrm{yr}$ $(0.05 \pm 0.024$ cycles per year) is found in records $07-1,07-2$, 07-5, 07-7 and 08-4 (Fig. 6). This long-term periodicity in $\mathrm{rBC}$, which is not related to Na, suggests a link to fire emission variability or long-range upper atmospheric transport. 
However, both may be linked to ENSO. Indeed, this periodicity is found to correspond to an ENSO reconstruction derived from the North American Drought Atlas (NADA) (Li et al., 2011), which is anti-correlated to the large-scale $\mathrm{rBC}$ variability observed in Fig. 3d (scale inverted). Here, higher rBC concentrations are associated with low variance periods ( $\mathrm{La}$ Niña, colder) and lower concentrations during high variance periods (El Niño, warmer). This suggests that increased $\mathrm{rBC}$ emissions from fire drive higher $\mathrm{rBC}$ loading of the Antarctic atmosphere during decadal time periods dominated by $\mathrm{La}$ Niña.

\section{Conclusions}

Concentrations of $\mathrm{rBC}$ found in the NUS ice cores reveal both spatial and temporal variability during the 1800-2000 time period. Spatial variability was primarily associated with changes in elevation and is likely linked to increased atmospheric loading in $\mathrm{rBC}$ and/or decreased accumulation with altitude. Relatively stable net snow accumulations rates at the NUS sites (Anschütz et al., 2011) suggest that decadal variability is related to changes in the $\mathrm{rBC}$ aerosol in the overlying air. On the other hand, the absence of strong correlations between the records may suggest that site-specific atmospheric transport and surface processes influence $\mathrm{rBC}$ concentrations at these sites. This is confirmed by high correlation and coherence coefficients between $\mathrm{Na}$ and $\mathrm{rBC}$ for some of the sites. This observation is different from the results obtained at WAIS and Law Dome by Bisiaux at al. (2012). Indeed, at those low elevation sites, it was shown that most of the recorded $\mathrm{rBC}$ variability was independent from atmospheric transport, which modulates the $\mathrm{Na}$ record. However, spectral analysis revealed the existence of non-transport oscillatory signals common to almost all the records. Common features in the records' non-linear trends, showing relatively low concentrations from 1890 to 1910 , high concentrations until 1930 and an increasing trend at the end of the 21 st century, confirm the presence of a variability linked to rBC sources only. Nevertheless, while large-scale changes in $\mathrm{rBC}$ deposition at WAIS and Law Dome were found to correspond to a change in anthropogenic activities, measurements from the East Antarctic Plateau suggest a link with ENSO long-term emissions. In any case, global climate and aerosols models may enlighten the variability of rBC deposition to Antarctica, and the apportionment between the various continental sources.

Acknowledgements. This research is based upon work supported by the National Science Foundation under Grant Numbers 0733089, 0538185, 0538416, 0538595 and has been carried out under the umbrella of TASTE-IDEA within the framework of IPY project no. 152 jointly funded by the US National Science Foundation, the Norwegian Polar Institute, and the Research Council of Norway. The project is part of the Trans-Antarctic Scientific Traverse Expeditions - Ice Divide of East Antarctica (TASTE-IDEA), and the International Partners in Ice Coring Sciences (IPICS) under the ISCU-WMO endorsement for the International Polar Year 2007-08 and 2008-09. We gratefully acknowledge the NUS traverse field teams, the National Science Foundation, the Norwegian Polar Institute, and the DRI ice core analysis team. Logistic support in Antarctica was provided by Raytheon Polar Services in Antarctica, and the 109th New York Air National Guard. The National Ice Core Laboratory, which archived the ice cores and preformed core processing, is funded by the National Science Foundation.

Edited by: P. Quinn

\section{References}

Andreae, M. O., Jones, C. D., and Cox, P. M.: Strong present-day aerosol cooling implies a hot future, Nature, 435, 1187-1190, 2005.

Anschütz, H., Müller, K., Isaksson, E., McConnell, J. R., Fischer, H., Miller, H., Albert, M., and Winther, J. G.: Revisiting sites of the South Pole Queen Maud Land Traverses in East Antarctica: Accumulation data from shallow firn cores, J. Geophys. Res., 114, D24106, doi:10.1029/2009jd012204, 2009.

Anschütz, H., Sinisalo, A., Isaksson, E., McConnell, J. R., Hamran, S.-E., Bisiaux, M. M., Pasteris, D., Neumann, T. A., and Winther, J.-G.: Variation of accumulation rates over the last eight centuries on the East Antarctic Plateau derived from volcanic signals in ice cores, J. Geophys. Res., 116, D20103, doi:10.1029/2011JD015753, 2011.

Bertler, N., Mayewski, P. A., Aristarain, A., Barrett, P., Becagli, S., Bernardo, R., Bo, S., Xiao, C., Curran, M., Qin, D., Dixon, D., Ferron, F., Fischer, H., Frey, M., Frezzotti, M., Fundel, F., Genthon, C., Gragnani, R., Hamilton, G., Handley, M., Hong, S., Isaksson, E., Kang, J., Ren, J., Kamiyama, K., Kanamori, S., Kärkäs, E., Karlöf, L., Kaspari, S., Kreutz, K., Kurbatov, A., Meyerson, E., Ming, Y., Zhang, M., Motoyama, H., Mulvaney, R., Oerter, H., Osterberg, E., Proposito, M., Pyne, A., Ruth, U., Simões, J., Smith, B., Sneed, S., Teinilä, K., Traufetter, F., Udisti, R., Virkkula, A., Watanabe, O., Williamson, B., Winther, J. G., Li, Y., Wolff, E., Li, Z., and Zielinski, A.: Snow chemistry across Antarctica, Ann. Glaciol., 41, 167-179, 2005.

Bisiaux, M. M., Edwards, R., McConnell, J. R., Curran, M. A. J., Van Ommen, T. D., Smith, A. M., Neumann, T. A., Pasteris, D. R., Penner, J. E., and Taylor, K.: Changes in black carbon deposition to Antarctica from two high-resolution ice core records, AD 1850-2000, Atmos. Chem. Phys., accepted, 2012.

Bowman, D. M. J. S., Balch, J. K., Artaxo, P., Bond, W. J., Carlson, J. M., Cochrane, M. A., D'Antonio, C. M., DeFries, R. S., Doyle, J. C., Harrison, S. P., Johnston, F. H., Keeley, J. E., Krawchuk, M. A., Kull, C. A., Marston, J. B., Moritz, M. A., Prentice, I. C., Roos, C. I., Scott, A. C., Swetnam, T. W., van der Werf, G. R., and Pyne, S. J.: Fire in the Earth System, Science, 324, 481-484, doi:10.1126/science.1163886, 2009.

Chung, C. E., Ramanathan, V., Kim, D., and Podgorny, I. A.: Global anthropogenic aerosol direct forcing derived from satellite and ground-based observations, J. Geophys. Res., 110, D24207, doi:10.1029/2005jd006356, 2005.

Crutzen, P. J. and Andreae, M. O.: Biomass burning in the tropics: Impact on atmospheric chemistry and biogeochemical cycles, 
Science, 250, 1669-1678, doi:10.1126/science.250.4988.1669, 1990.

Dube, O. P.: Linking fire and climate: interactions with land use, vegetation, and soil, Current Opinion in Environmental Sustainability, 1, 161-169, 2009.

Fischer, H., Siggaard-Andersen, M.-L., Ruth, U., Röthlisberger, R., and Wolff, E.: Glacial/interglacial changes in mineral dust and sea-salt records in polar ice cores: Sources, transport, and deposition, Rev. Geophys., 45, RG1002, doi:10.1029/2005rg000192, 2007

Flanner, M. G., Zender, C. S., Randerson, J. T., and Rasch, P. J.: Present-day climate forcing and response from black carbon in snow, J. Geophys. Res.-Atmos, 112., D11202, doi:10.1029/2006jd008003, 2007.

Ghil, M., Allen, M. R., Dettinger, M. D., Ide, K., Kondrashov, D., Mann, M. E., Robertson, A. W., Saunders, A., Tian, Y., Varadi, F., and Yiou, P.: Advanced spectral methods for climatic time series, Rev. Geophys., 40, 1003, doi:10.1029/2000rg000092, 2002.

Gilbert, R. O.: 6.5 Sen's Nonparametric Estimator of Slope, in: Statistical Methods for Environmental Pollution Monitoring, John Wiley and Sons, 217-219, 1987.

Isaksson, E., van den Broeke, M., Winther, J.-G., Karlöf, L., Pinglot, J., and Gundestrup, N.: Accumulation and proxytemperature variability in Dronning Maud Land, Antarctica, determined from shallow firn cores, Ann. Glaciol., 29, 17-22, 1999.

Ito, A. and Penner, J. E.: Global estimates of biomass burning emissions based on satellite imagery for the year 2000, J. Geophys. Res., 109, D14S05, doi:10.1029/2003jd004423, 2004.

Jacobson, M. Z.: Strong radiative heating due to the mixing state of black carbon in atmospheric aerosols, Nature, 409, 695-697, 2001.

Kaspari, S. D., Schwikowski, M., Gysel, M., Flanner, M. G., Kang, S., Hou, S., and Mayewski, P. A.: Recent increase in black carbon concentrations from a Mt. Everest ice core spanning 1860-2000 AD, Geophys. Res. Lett., 38, L04703, doi:10.1029/2010g1046096, 2011.

Krawchuk, M. A. and Moritz, M. A.: Constraints on global fire activity vary across a resource gradient, Ecology, 92, 121-132, doi:10.1890/09-1843.1, 2011.

Li, J., Xie, S.-P., Cook, E. R., Huang, G., D’Arrigo, R., Liu, F., Ma, J., and Zheng, X.-T.: Interdecadal modulation of El Nino amplitude during the past millennium, Nature Climate Change, 1, 114-118, 2011.

Limpert, E., Stahel, W. A., and Abbt, M.: Log-normal Distributions across the Sciences: Keys and Clues, BioScience, 51, 341-352, doi:10.1641/0006-3568(2001)051[0341:LNDATS]2.0.CO;2, 2001

Marlon, J. R., Bartlein, P. J., Carcaillet, C., Gavin, D. G., Harrison, S. P., Higuera, P. E., Joos, F., Power, M. J., and Prentice, I. C.: Climate and human influences on global biomass burning over the past two millennia, Nat. Geosci., 1, 697-702, doi:10.1038/ngeo313, 2008.

McConnell, J. R.: New Directions: Historical black carbon and other ice core aerosol records in the Arctic for GCM evaluation, Atmos. Environ., 44, 2665-2666, 2010.

McConnell, J. R., Edwards, R., Kok, G. L., Flanner, M. G., Zender, C. S., Saltzman, E. S., Banta, J. R., Pasteris, D. R., Carter, M. M., and Kahl, J. D. W.: 20th-century industrial black carbon emissions altered arctic climate forcing, Science, 317, 1381-1384, doi:10.1126/science.1144856, 2007.

Moosmüller, H., Chakrabarty, R. K., and Arnott, W. P.: Aerosol light absorption and its measurement: A review, J. Quant. Spectrosc. Ra., 110, 844-878, 2009.

Mouillot, F. and Field, C. B.: Fire history and the global carbon budget: a $1^{\circ} \times 1^{\circ}$ fire history reconstruction for the 20th century, Glob. Change Biol., 11, 398-420, doi:10.1111/j.13652486.2005.00920.x, 2005.

Nadaraya, E. A.: On Non-Parametric Estimates of Density Functions and Regression Curves, Theory Probab. Appl., 10, 186190, doi:10.1137/1110024, 1965.

Nitschke, C. R. and Innes, J. L.: Climatic change and fire potential in South-Central British Columbia, Canada, Glob. Change Biol., 14, 841-855, doi:10.1111/j.1365-2486.2007.01517.x, 2008.

Önöz, B. and Bayazit, M.: The Power of Statistical Tests for Trend Detection, Turkish J. Eng. Env. Sci., 27, 247-251, 2003.

Paillard, D., Labeyrie, L., and Yiou, P.: Macintosh program performs time-series analysis, Eos Trans. AGU, 77, 379-379, 1996.

Penner, J. E., Zhang, S. Y., Chin, M., C.C. Chuang, J. Feichter, Y. Feng, I.V. Geogdzhayev, P. Ginoux, M. Herzog, A. Higurashi, D. Koch, C. Land, U. Lohmann, M. Mishchenko, T. Nakajima, G. Pitari, B. Soden, I. Tegen, and Stowe, L.: A comparison of model -and satellite-derived aerosol optical depth and reflectivity, J. Atmos. Sci., 59, 441-460, 2002.

Pomeroy, J. W., Davies, T. D., Jones, H. G., Marsh, P., Peters, N. E., and Tranter, M.: Transformations of snow chemistry in the boreal forest: accumulation and volatilization, Hydrol. Process., 13, 2257-2273, doi:10.1002/(sici)10991085(199910)13:14/15<2257::aid-hyp874>3.0.co;2-g, 1999.

Ramanathan, V. and Carmichael, G.: Global and regional climate changes due to black carbon, Nat. Geosci., 1, 221-227, doi:10.1038/ngeo156, 2008.

Ramanathan, V., Crutzen, P. J., Kiehl, J. T., and Rosenfeld, D.: Atmosphere - Aerosols, climate, and the hydrological cycle, Science, 294, 2119-2124, 2001.

Schwarz, J. P., Spackman, J. R., Gao, R. S., Watts, L. A., Stier, P., Schulz, M., Davis, S. M., Wofsy, S. C., and Fahey, D. W.: Global-scale black carbon profiles observed in the remote atmosphere and compared to models, Geophys. Res. Lett., 37, L18812, doi:10.1029/2010g1044372, 2010.

Seiler, W. and Crutzen, P. J.: Estimates of gross and net fluxes of carbon between the biosphere and the atmosphere from biomass burning, Clim. Change, 2, 207-247, 1980.

Skeie, R. B., Berntsen, T., Myhre, G., Pedersen, C. A., Ström, J., Gerland, S., and Ogren, J. A.: Black carbon in the atmosphere and snow, from pre-industrial times until present, Atmos. Chem. Phys., 11, 6809-6836, doi:10.5194/acp-11-6809-2011, 2011.

Sneed, S. B., Mayewski, P. A., and Dixon, D. A.: An emerging technique: multi-ice-core multi-parameter correlations with Antarctic sea-ice extent, Ann. Glaciol., 52, 347-354, 2011.

Sodemann, H. and Stohl, A.: Asymmetries in the moisture origin of Antarctic precipitation, Geophys. Res. Lett., 36, L22803, doi:10.1029/2009g1040242, 2009.

Stohl, A.: Characteristics of atmospheric transport into the Arctic troposphere, J. Geophys. Res., 111, D11306, doi:10.1029/2005jd006888, 2006.

Vautard, R. and Ghil, M.: Singular spectrum analysis in nonlinear dynamics, with applications to paleoclimatic time series, Physica D: Nonlinear Phenomena, 35, 395-424, 1989. 
Wang, Z., Chappellaz, J., Park, K., and Mak, J. E.: Large Variations in Southern Hemisphere Biomass Burning During the Last 650 Years, Science, 330, 1663-1666, doi:10.1126/science.1197257, 2010.
Watson, G. S.: Smooth Regression Analysis, Sankhyā: The Indian Journal of Statistics, Series A (1961-2002), 26, 359-372, 1964. 